\title{
Compounds and Methods to Resensitize Antibiotic-resistant Bacteria
}

\author{
Antibiyotiğe Dirençli Bakterileri Yeniden Duyarlılaştırmak için Kullanılan Bileşikler ve \\ Yöntemler
}

\author{
(1) Priya SWAMINATHAN, (1) Suravi SEN, (1) Mandira M.A., (1) Abhirami A. PRASAD \\ SRM Institute of Science and Technology, Department of Biotechnology, Tamil Nadu, India
}

\section{Abstract}

The resistance of bacteria to the bacteriostatic and bactericidal properties of antibiotics is a major healthcare challenge that restricts the use of different types of available antibiotics. A potential alternative is to resensitize multidrug-resistant bacteria using resistance-modifying chemicals, therapies, or compounds, which act collaboratively with existing antibiotics against infections. Thus, we deliberate over the scope of various compounds, such as $2 \mathrm{Al}$ compounds, certain plant extracts, and other chemicals to understand their role in inducing sensitivity. One of the major components, $\mathrm{H}_{2} \mathrm{~S}$, is known to be cytotoxic and has shown various effects on bacteria. Endogenous $\mathrm{H}_{2} \mathrm{~S}$ provides resistance to various bacterial species. Incidentally, an ongoing research is investigating how exogenous $\mathrm{H}_{2} \mathrm{~S}$ can induce sensitivity in bacteria. Therefore, in the future, alternatives or advancements in existing antibiotics and therapies will be needed to fight bacterial diseases.

Keywords: Antibiotic resistance, antibiotics, bacterial sensitivity, combined therapy

\section{Öz}

Bakterilerin antibiyotiklerin bakteriyostatik ve bakterisidal özelliklerine karşı direnci, farklı tipte antibiyotiklerin kullanımını kısıtlayan önemli bir sağlık sorunudur. Potansiyel bir alternatif, enfeksiyonlara karşı mevcut antibiyotiklerle işbirliği içinde hareket eden direnci değiştiren kimyasallar, terapiler veya bileşikler kullanarak çoklu ilaca dirençli bakterileri yeniden duyarlı hale getirmektir. Bu nedenle, 2Al bileşikleri, belirli bitki özleri ve diğer kimyasallar gibi çeşitli bileşiklerin duyarlılığı indüklemedeki rollerini anlamak için bu tip bileşikler üzerinde tartışmak istedik. Ana bileşenlerden biri olan $\mathrm{H}_{2} \mathrm{~S}$ 'nin sitotoksik olduğu bilinmektedir ve $\mathrm{H}_{2} \mathrm{~S}$ bakteriler üzerinde çeşitli etkiler göstermektedir. Endojen $\mathrm{H}_{2} \mathrm{~S}_{1}$ çeşitli bakteri türlerine karşı direnç sağlar. Bu arada, devam eden bir araştırma, eksojen $\mathrm{H}_{2} \mathrm{~S}$ 'nin bakterilerde duyarlılığı nasıl indükleyebileceğini araştırmaktadır. Bu nedenle gelecekte bakteriyel hastalıklarla savaşmak için mevcut antibiyotiklerde ve tedavilerde alternatiflere veya gelişmelere ihtiyaç duyulacaktır.

Anahtar Kelimeler: Antibiyotik direnci, antibiyotikler, bakteriyel duyarlılık, kombine tedavi

\section{Introduction}

In recent times, the world has witnessed the extensive increase in antibiotics due to the increased occurrence of diseases, and we have been able to combat diseases due to the improvement in our medical and health facilities. According to the World Health Organization, the increase in antibiotic resistance is due to the misuse and extensive use of antibiotics, causing poor prevention and inability to restrain infection. Antibiotic resistance is the life-threatening condition when bacteria develop resistance to an antibiotic's bactericidal or bacteriostatic properties.

Multiple drug resistance (MDR) occurs when a single bacterium becomes resistant to multiple antibiotics. Multiple drug resistance emerged in the late 1950s to the early 1960 s. Initially, MDR was observed in gastrointestinal or foodborne pathogens, such as E. coli, Shigella, and Salmonella. Multiple

Cite this article as: Swaminathan P, Sen S, M.A. M, A. Prasad A. Compounds and Methods to Resensitize Antibiotic-resistant Bacteria. Mediterr J Infect Microb Antimicrob. 2021;10:46. 
drug resistance has also spread to other common pathogens, including Haemophilus influenza which developed resistance toward ampicillin, chloramphenicol, and tetracycline. Neisseria gonorrhea is a sexually transmitted disease pathogen that developed resistance toward ampicillin mainly during the 1970s in developed countries. Antibiotic resistance was initially observed in the 1930s to the 1940s in hospitals where most drugs were prescribed. Waste generated by hospitals was one of the reasons for the development of antibiotic resistance, for example, the sulfonamide resistance of Streptococcus progeneses and penicillin resistance of Staphylococcus aureus. Lately, common bacteria, such as Klebsiella pneumoniae, Staphylococcus aureus, and E. coli, have developed high rates of antibiotic resistance.

Ongoing research has shown that compounds administered along with an antibiotic can increase its efficacy, thus making bacteria susceptible to antibiotics again. Sensitizing methods also offer a significant economic advantage by greatly increasing the lifespan of current antibiotics. The evolutionary pressure on sensitizers to develop resistance, although not completely absent, is significantly lower than that on antibiotics that directly kill bacteria. Various compounds, such as metal ions, chemical compounds such as $\mathrm{H}_{2} \mathrm{~S}$, and plant extracts, have shown properties that resensitize antibiotic-resistant bacteria for certain antibiotics. Several studies have shown that technologies, such CRISPR/CAS9, can be used to target specific sequences that can act effectively on certain resistant microbiological strains. These compounds and methods will help us cure certain diseases better in the future (Table 1).

\section{Chemosensitizers}

Chemosensitizers are small molecules that can improve or increase the therapeutic index of drugs by making tumor cells susceptible to chemotherapeutics. These molecules can overcome resistance, thus making the treatment easier. Chemosensitizers can channel high concentrations of drug to their target sites by inhibiting drug efflux. Mostly, chemosensitizers work as competitive or non-competitive inhibitors, but they can also bind to other drug interaction sites and work as allosteric inhibitors. These compounds have shown a high affinity toward Pgp, modulating changes to achieve pharmacological actions.

The in vitro sensitivity of the methicillin-resistant Staphylococcus aureus (MRSA) strain to cefazolin and oxacillin increased in the presence of sodium hydrogen carbonate $\left(\mathrm{NAHCO}_{3}\right)$ supplementation, according to a study focusing on the betalactam agent's activity in the presence or absence of $\mathrm{NAHCO}_{3}$; a supplemented medium was used to treat methicillin-susceptible S. aureus infections ${ }^{[6]}$.

Acquired sulfonamide fastness is possible because of the increase in $\mathrm{P}$ factor, which if reduced, neutralized, or managed to certain levels, can overcome the acquired sulfonamide fastness. Urea overcomes the anti-sulfonamide action of methionine or p-aminobenzoic acid for $S$. aureus species growing in a synthetic medium, but the inhibiting concentration did not exhibit a considerable effect on the bacterial growth rate ${ }^{[7]}$. The entire mechanism and its effectiveness on an extensive range of species are still under research, but the combined effect of urea along with sulfonamide compound (sulfathiazole) has been a new interest for clinical remedies.

Another study on reference strain PA01, which was screened for high content, permitted four polyamine isoprene compounds to work in tandem with doxycycline. This strain, which is generally resistant to antibiotics, was used as an escort molecule for re-sensitization. The polyamine isoprene compounds were tested against MDR strains, and one of them lowered the minimum inhibitory concentration (MIC) of the antibiotic doxycycline on the reference, suggesting the re-sensitization of

Table 1. A table indicating a few compounds than has the capacity to resensitize and their target action

\begin{tabular}{|c|c|c|c|c|}
\hline Compound & Type & Kind of action & Bacteria & Antibiotics \\
\hline $\begin{array}{l}\text { Gallium, sidephore } \\
\text { quencher and furanone } \\
\text { C-30, OS inhibitor }\end{array}$ & $\begin{array}{l}\text { Addition of } \\
\text { antivirulence } \\
\text { compounds to } \\
\text { antibiotics }\end{array}$ & $\begin{array}{l}\text { Restores growth } \\
\text { inhibition and affects } \\
\text { selection for antibiotic } \\
\text { resistance }\end{array}$ & Pseudomonas aeruginosa & $\begin{array}{l}\text { Ciprofloxacin, colistin, } \\
\text { meropenem, tobramycin }^{[1]}\end{array}$ \\
\hline Tricyclic indoline & $\begin{array}{l}\text { Plant-based } \\
\text { product }\end{array}$ & $\begin{array}{l}\text { Selectively resensitize } \\
\text { MRSA }\end{array}$ & Staphylococcus aureus & Beta-lactam antibiotics $^{[2]}$ \\
\hline $\begin{array}{l}\text { Clerodane diterpene from } \\
\text { C. americana }\end{array}$ & $\begin{array}{l}\text { Plant-based } \\
\text { products }\end{array}$ & $\begin{array}{l}\text { Selectively resensitize } \\
\text { MRSA }\end{array}$ & Staphylococcus aureus & Beta-lactam antibiotics ${ }^{[3]}$ \\
\hline $\mathrm{H}_{2} \mathrm{~S}$ & $\begin{array}{l}\text { Chemical } \\
\text { compounds }\end{array}$ & $\begin{array}{l}\text { Exogenous exposure to } \\
\text { antibiotics in bacteria not } \\
\text { producing } \mathrm{H}_{2} \mathrm{~S}\end{array}$ & Acinetobacter baumannii & $\begin{array}{l}\text { Gentamycin, colistin, rifampicin, } \\
\text { and clarithromycin }{ }^{[4]}\end{array}$ \\
\hline Selenoenzymes & Antioxidants & $\begin{array}{l}\text { Se-enriched bacteria } \\
\text { alleviating negative } \\
\text { effects of oxidative stress }\end{array}$ & $\begin{array}{l}\text { Escherichia coli (ATCC25922) } \\
\text { and Staphylococcus } \\
\text { aureus (ATCC25923) }\end{array}$ & Ciprofloxacin ${ }^{[5]}$ \\
\hline
\end{tabular}

MRSA: Methicillin-resistant Staphylococcus aureus 
a naturally resistant strain. The substances were characterized using membrane permeation assays and time efflux tests. Chloramphenicol, when used as an antibiotic, exhibited a similar trend as doxycycline ${ }^{[8]}$. This finding proves that chemosensitizers can increase the susceptibility of $P$. aeruginosa to doxycycline, which is naturally resistant. Recent studies on $E$. coli and $P$. aeruginosa showed that when hydrophilic compounds were co-administered at a concentration less than half of their MIC and antimicrobials, enhanced efficiency of up to 30-folds was observed. Claramine $A 1$, the first of a new generation of powerful antimicrobials, has a unique multifaceted mechanism of action that works against Gram-positive and Gram-negative bacteria ${ }^{[9]}$.

Another combined therapy consisting of auranofin and colistin can rescue the infection of $E$. coli. Auranofin combined with antibiotics is also expected to combat superbugs ${ }^{[10]}$. Auranofin can synergize with antibiotics to kill a broad spectrum of colistin and carbapenem-resistant bacteria. Auranofin can displace zinc cofactors from their active sites, thus disrupting their enzyme activity and slowing down the development of beta-lactam and colistin resistance.

Chemosensitizers can act through different channels or acts as inhibitors to combat antibiotic resistance, thus serving an important concept of clinical interest.

\section{$\mathrm{H}_{2} \mathrm{~S}$}

$\mathrm{H}_{2} \mathrm{~S}$ has been used to confirm antibiotic tolerance in microorganisms; however, a recent study established that if $\mathrm{H}_{2} \mathrm{~S}$ is added externally, it can trigger certain chemical reactions that can eventually lead to re-sensitization of previously resistant bacteria; this specific experiment was performed on Acinetobacter baumannii, which is pathogenic in nature and does not produce hydrogen sulfide endogenously ${ }^{[11]}$. $A$. baumannii is resistant to a wide range of antibiotics. This research has especially become a major point of interest in antibiotics and multidrug-resistant studies given its potential to cause revolutionary changes clinically. Numerous species that can generate endogenous hydrogen sulfide, whose role is unknown, have shown a high range of sensitivity toward a variety of antibiotics when certain enzymes, such as cystathionine betasynthase, cystathionine gamma-lyase, etc., are inactivated. This event was specifically observed in P. aeruginosa, E. coli, and Bacillus anthracis ${ }^{[12]}$. Studies have shown that $\mathrm{H}_{2} \mathrm{~S}$-mediated drug resistance depends on the reduction of oxidative stress from the drugs.

Another study focused on how hydrogen sulfide controls antimicrobial resistance and protects bacteria from antibioticinduced stress and demonstrated that $\mathrm{H}_{2} \mathrm{~S}$ helps in maintaining the redox homeostasis. However, antibiotic resistance in several clinical bacteria can be reversed by inhibiting biosynthesis chemically, although the related pathway remains unknown. This phenomenon was also observed in E. coli, which produces hydrogen sulfide endogenously ${ }^{[13]}$.

Recent studies have shown that the addition of exogenous hydrogen sulfide to multidrug-resistant bacterial strains can resensitize bacteria against certain drugs or antibiotics to a greater extent than antibiotics alone. Hence, this compound can work in various lethal medical concerns.

\section{Phage Therapy}

Phage therapy is one of the advanced therapies that use bacteriophages to treat pathogenic bacterial infections. Phages are a form of viruses that can act against treatable and drugresistant bacteria mainly by lysis. Phage can infect bacteria by injecting its genes and initiating a rapid multiplication, leading to the rupture of bacterial cells and release of new bacteriophages. One major benefit of this method is that phages are non-toxic to the body and affects only bacteria.

A research investigated the effectiveness of age-old antibiotics, phage therapy, and a combination of both in broiler chickens with $E$. coli, and the results showed that only phage therapy decreased mortality in untreated birds (15\%), whereas standard antibiotics caused a reduction from $68 \%$ to $3 \%$. The combination of the two methods, on the other hand, resulted in zero mortality ${ }^{[14]}$. In a related experiment, rats with endocarditis were given phage in combination with ciprofloxacin; compared with antibiotics or phage alone, the combined treatment resulted in a 10,000-fold reduction in bacterial load. The combination acted on the bacteria by synergistic killing.

Another study involving carbapenem-resistant Acinetobacter baumannii, which can result in fatal infections, used phage therapy to combat its adversity, gaining significant medical interest. A major drawback here is that the bacterium can develop resistance against the phage. Loss-of-function mutations in novel phage resistance genes, which are responsible for the creation of the bacterial capsule, were discovered in a study on a primary receptor for phages ${ }^{[15]}$. Thus, apart from their lytic ability, phages can be combined based on knowledge on their receptors and mechanisms, offering a broader spectrum of clinical therapies.

\section{Bacteriophages}

Bacteriophages are bacteria-specific viruses that only affect and replicate in bacteria. For a variety of purposes, phages are clinically important. Bacteriophage genomes encode a large number of highly pathogenic bacterial toxins. Thus, the host bacterium only becomes pathogenic when the toxinencoding phage lyses it. Without their phage-encoded toxins, these bacterial organisms are notably less pathogenic, if not non-pathogenic at all. Second, bacteriophages may be used 
to transfer horizontal genes, such as antimicrobial resistance genes. Third, a clinically significant feature of bacteriophages is that they can be identified in a complex environmental sample as a biomarker for their host ${ }^{[16]}$. Antibiotics potentially encourage the growth of bacteriophages and phage-encoded products and the dissemination of virus and pathogenicity genes, all of which can have serious consequences on disease intensity. With the unwanted side effects and MDR crisis, phage therapy has resurfaced. Phages bind to specific receptors and inject their genome into the bacterial cell. When the phage genetic material enters the cytoplasm, it can either merge into the genetic material or remain as unintegrated additional genomic genetic material ${ }^{[17]}$. The lytic phase is followed by a virulent phage where multiple copies of the phage are produced by integrating their genome into the host, ultimately resulting in cell lysis. Temperate phages revert to lysogeny and integrate into the genome of their hosts before mutagenic stress induces them to enter the lytic life cycle.

Phage therapy has made considerable progress owing to wholegenome analysis, automated microbial growth measurement technology, and high-throughput screening methods that can screen dozens or hundreds of samples at once. This progress led to the advancement of conventional phage therapy, resulting in a phage-transferable CRISPR-Cas system. The technology employs CRISPR spacers, which may be rationally tailored to bind any DNA sequence, including resistance genes and lytic phages. Thus, a property that favors bacteria (for example, spacers that guard against lytic phage) can be genetically linked to a characteristic that reverses drug resistance (i.e., spacers targeting resistance genes). Using lytic phages, the genetic linkage enables the collection of antibiotic-sensitized bacterial populations. The integrated design aims to aggressively eliminate existing resistant gene while also blocking horizontal gene transfer among bacteria ${ }^{[18]}$. The system CRISPR-Cas, which may be programmed to exclude any desired gene, can easily sensitize bacteria to different genes with antibiotic resistance. Given its short sequence, decades of distances in a single array can be developed to reuse resistance to a wide range of antibiotics. Theoretically, a mixture of several antibiotics can probably simultaneously develop pathogenic resistance in the treatment of bacterial infections. With a lytic phage mixture, the development of lytic phage resistance can also be minimized. An array of multiple facets may be used to protect multiple lytic phages against sitting and reducing the occurrence simultaneously of non-sensitized bacterial mutants escaping lytic phages. Finally, the goal is the possible use of multiple spacers in every resistant gene and lytic phage to reduce the likelihood of CRISPR escape mutants ${ }^{[19]}$.

If this technology is used in the future, drug-resistant pathogen populations in major sources of contamination should be reduced. As a result, antibiotics that are currently resistant may be effective once more. Although forcing bacteria to evolve to avoid phage attack, severe screening opposing bacterial virulence and resistance to antibiotics is also enforced. Lytic phages are far more efficient than phage therapy because they kill the target bacteria. A phage that utilizes antibiotic efflux pumps as a receptor is more vulnerable to antibiotics than phage-resistant bacterial mutants with faulty efflux pumps. Phages that bind to structural virulence factors, such as the capsular antigen, may select phage-resistant bacterial mutants lacking the shell; given that phage-resistant mutants are easily engulfed by phagocytic cells, they are less virulent ${ }^{[20]}$. In E. coli, phage TLS was picked at a frequency of $10^{5}$ to $10^{6}$ cells for TolC and rfa mutants. TLS-resistant mutants with mutated TolC were hypersensitive to Novobiocin. When phageresistant mutants were selected in the presence of novobiocin, the prevalence of recovered variants was 1,000-fold lower. The opportunistic pathogen's outer membrane protein M (OprM) i.e., $P$. aeruginosa's MexAB- and Mex-XY-OprM efflux pumps, were recently discovered to be associated with phage OMKO1. As a "genetic trade-off", this relationship favors phage-resistant mutants who are antibiotic-sensitive. In laboratory strains and clinical isolates of $P$. aeruginosa, Kortright et al. ${ }^{[21]}$ discovered that phage-resistant mutants are more vulnerable to medicines such as ceftazidime.

The mechanism of action of this strategy is likely to be entirely different from that of current antimicrobials, which is one of its possible advantages. The difficulty of quality control and standardization is one of the disadvantages. Phages are also likely to be immunogenic when used systemically in patients and may cause neutralizing antibodies ${ }^{[17]}$. Massive bacterial lysis may lead to toxic shock. Bacterial resistance to phages develops rapidly, necessitating the use of a mixture of phages to counteract resistance. Despite these limitations, the introduction of a phage-transferable CRISPR-Cas device can be the answer to the MDR problem.

\section{Adjuvants}

Adjuvants are chemical entities that rarely possess any antibiotic activity that enhances the immune system's response to an antigen. They are commonly administered along with antigens to improve the effectiveness of vaccines. Lately, given that the emergence of MDR genes has rendered life-saving antibiotics less effective, the combined therapy of existing antibiotics with adjuvants known as "Antibody Adjuvants" has been developed. Antibiotic adjuvants re-empower antibiotics, making them more effective against resistant strains. The key role of adjuvants is to perform polypharmacy. Adjuvants are grouped into three: group 1 is engineered to have extremely low intrinsic antibacterial activity, whereas group 2 uses an auxiliary compound to change the bacteria's permeability. Chemicals in 
group 3 function directly on the target or potentiate the action of antibiotics by influencing the host's characteristics. Bacteria have developed resistance through various mechanisms, such as target modification, efflux pumps, and inactivation of antibiotics by hydrolysis, beta-lactamases, and transferable resistance. Adjuvants, including beta-lactamase inhibitor, efflux pump inhibitors (EPIs), and outer sheath permeabilizers, are used to restore the sensitivity of bacteria to antibiotics ${ }^{[22]}$.

Bacteria can produce an enzyme that can hydrolyze antibiotics and beta-lactamases. Countering this effect, beta-lactamase inhibitors were introduced into the therapeutic market in the 1970s. These inhibitors are of two types: reversible inhibitors that bind to the enzyme intrinsically and irreversible ones that use the structure of beta-lactams or a suitable isostere to bind to or close the lactamase enzyme's active site and inhibit its activity. Amoxicillin plus clavulanic acid is the most common combination marketed under the trade name Augmentin, and it is still being used for the treatment of a broad range of conditions. Clavulanic acid and amoxicillin work together to prevent amoxicillin from being hydrolyzed via establishing an irreversible connection with a serine residue in the functional site of the beta-lactamase. Potassium clavulanate is ineffective against pathogens, but it effectively inhibits several forms of extended spectrum beta-lactamase (ESBLs) that can hydrolyze penicillin, monobactams, and cephalosporins. Antibiotic-resistant bacteria are responsive to antibiotics when aspergillomarasmine A (AMA), a polyaminoacid derived from Aspergillus versicolor, inhibits NDM-1 and VIM antibiotic resistance carbapenemase proteins in microorganisms. A singular dosage of meropenem (10 mg/kg body weight) + AMA (30 $\mathrm{mg} / \mathrm{kg}$ ) resulted in 95\% survival five days after infection of a mouse model of NDM-1-positive $K$. pneumonia infection, whereas meropenem or AMA alone at the same dosages resulted in $0 \%$ survival. When ampicillin was combined with AMA, the MIC value fell from $32 \mathrm{~g} / \mathrm{ml}$ to $1 \mathrm{~g} / \mathrm{ml}$. Avibactum, a covalent reversible inhibitor with a strong binding, was discovered in 2015. However, Klebsiella pneumoniae carbapenemase (KPC)-2 inhibits most enzymes. Given that KPC-2 is hydrolyzed slowly, it retains its therapeutic efficacy. Global inhibitors are a class of inhibitors known as cyclic boronates and serve as the initial analogs of tetrahedral intermediates, similar to metallo betalactamase and serine beta-lactamase in the hydrolysis pathways catalyzed by these enzymes. This finding was confirmed by an $\mathrm{X}$-ray structural investigation of a cyclic boronate complexed with the beta-lactamase CTX-M-15. This condition allows the adjuvants to block $A 71$ ESBL, CTX-M-15, class C enzymes, and two oxa-hydrolyzing carbapenemase versions, namely, 0xa-23 and 0xa-48. When these inhibitors were administered with piperacillin and cefazolin, the MIC was reduced by four times, whereas for ceftazidime and cefepime, the difference was eightfold ${ }^{[23]}$.
With growing MDR rendering infections untreatable, EPIs are used along with antibiotics to increase the efficacy of drugs. Efflux pumps are membrane carriers that protect by pumping out therapeutic agents from the bacterial cell. The overexpression of these pumps confers resistance. EPI blocks these pumps, thus overcoming resistance. Efflux pumps can be targeted in a variety of ways, such as a) suppressing the expression of genes that code for these pumps, b) hindering the assembly of pump components at the membrane level, c) blocking the expression of genes encoding these pumps, or $d$ ) decreasing the required energy for these pumps to operate. The type of pathogenic bacteria to be targeted, the type of pump to be stopped, and the nature of antibiotic potential must all be considered when creating EPIs. The effectiveness of quinoline derivatives was tested on Enterobacter aerogenes multiple drug-resistant strains expressing AcrAB efflux pumps. The most active derivative was 7-nitro-8-methyl-4-(2'-(piperidinyl ethyl)-aminoquinoline, which has a piperidinyl ethyl-branched side chain. A significant reduction in MIC values was observed when combined with the antibiotics norfloxacin, tetracycline, and chloramphenicol. In 2015, 3,4-dibromopyrole-2,5-diole was isolated from a marine microbial extract. When combined with antibiotics, including ciprofloxacin, erythromycin, and chloramphenicol, the compound acts as a pump inhibitor. The capability to create a dose-dependent increase in fluorescence is caused by the accumulation of fluorescent dye corroborating the inhibitory activity ${ }^{[22,23]}$.

The last category of antibody adjuvants includes the membrane permeabilizers. Antibiotics currently in use work at the intracellular level. Hydrophobic compounds and hydrophilic molecules assist antibiotics to penetrate the membrane. However, through modification of membrane lipids and carriers, bacteria have grown resistant. With an improved understanding of the membrane composition and through various studies, surfactants, detergents, and polymyxins can be used along with antibiotics to overcome this obstacle. When given with aminoglycosides, menadione, a soluble synthetic vitamin that is converted to vitamin $\mathrm{K} 2$ in the intestine, reduces the MIC toward Pseudomonas aeruginosa. Antibiotics, novobiocin, and erythromycin are more effective when combined with the synthetic equivalent of the Joro-spider poison methoctramine, which is naphthyl acetyl spermine. This compound works as a membrane permeabilizer in $E$. coli, allowing antibiotics to pass through the outer membrane more easily ${ }^{[22,23]}$.

No challenges have been found in the adjuvant approach. Identifying compounds with the same physicochemical properties that are needed to access bacterial targets is the main challenge. As with any combination therapy, harmful drug-drug interactions pose a risk, and for an efficient codosing strategy, the antibiotic and adjuvant must have similar pharmacokinetic 
and pharmacodynamic properties. The decision to combine an inhibitor with a specific antibiotic is complicated and involves certain considerations. The capacity of an inhibitor to shield the antibiotic from enzymatic hydrolysis, the amount of inhibitor necessary to accomplish this protection, and the combination's overall viability and stability are all aspects to consider. Finding a compound that satisfies all these criteria is a laborious task. However, the growing list of advantages of using antibiotic adjuvants overcomes the hardships. Relative infancy can lead to the discovery of a great number of undiscovered targets and previously unidentified chemical scaffolds. Although the development of new antibiotics and improvements in antibiotic stewardship is critical, the use of complementary approaches to combat antibiotic resistance, such as the development of adjuvants, represents a powerful and underutilized weapon ${ }^{[22-24]}$.

\section{Plant}

Before the emergence of our present-day medicines, plant-based treatment was relevant and has been used for centuries. With the emergence of antibiotic-resistant bacteria, plants are being widely researched to find viable methods in this field. Phenolics and polyphenols, such as flavonoids, quinones, tannins, and coumarins, are the most commonly used antimicrobial agents, followed by alkaloids, terpenoids, lectins, and polypeptides and mixtures of their derivatives ${ }^{[25,26]}$. Various plant derivatives (plant-derived substances or plant derivative antimicrobials) are being used for treatment. Plant-derived substances are effective in disrupting the synthesis of the cell membrane, adenosine triphosphate generation of bacteria through chemicals such as thymol, catechins, eugenol, cinnamaldehyde, etc. ${ }^{[25,27]}$. One research showed that the plant metabolite sesquiterpene farnesol increased the susceptibility to beta-lactam in MRSA by targeting the cell wall formation and the murein monomer precursor transport ${ }^{[28]}$.

Various studies reported the synergetic effect between antibiotics and plant derivatives. Clerodane diterpene (16)dihydroxycleroda-3,13-dien-15,16-olide) from Callicarpa americana was proven to be beneficial against MRSA when combined with oxacillin ${ }^{[3]}$. A similar result was found in another research in which the tricyclic indoline, Of1, increased the activity of beta-lactam toward MRSA ${ }^{[29]}$. Ethanolic extracts of plants also potentiate the activity of antibiotics. Extracts of Camellia sinensis showed synergism with ampicillin and tetracycline ${ }^{[30]}$.

\section{Animal Derivatives}

Animal derivatives are slightly tougher to obtain and process compared with plants, but researchers have investigated this field and found capable products to work with antibiotics to inhibit or decrease antibiotic resistance.
A group of researchers derived a peptide toxin from the wasp Vespula lewisii. The peptide obtained was called mast-MO with an alpha-helical structure. The compound showed the most effective action with antibiotics, having protein-blocking machinery similar to kanamycin and gentamicin against $E$. coli and $A$. baumannifi[31].

\section{Conclusion}

Antibiotic resistance is a serious issue that requires more knowledge and comprehensive research to tackle the future scenario efficiently. Alternatives of antibiotics, such as phage therapy, chemical compounds, adjuvants, bacteriophages, or combined therapy, can rationalize the use of antibiotics and improve their quality and efficiency in the treatment of diseases. Various research and ongoing studies have proven that these alternatives can work radically against pathogens that may develop global resistance in the future. Multiple drug resistance, which attracts global interest, can be prevented from being a major problem for mankind with these new technologies and medical advancements.

\section{Ethics}

Peer-review: Externally peer-reviewed.

\section{Authorship Contributions}

Concept: P.S., A.A.P., Design: P.S., Data Collection or Processing: S.S., M.M.A., Analysis or Interpretation: A.A.P., Literature Search: S.S., M.M.A., Writing: P.S., S.S., M.M.A.

Conflict of Interest: No conflict of interest was declared by the authors.

Financial Disclosure: The authors declared that this study received no financial support.

\section{References}

1. Rezzoagli C, Archetti M, Mignot I, Baumgartner M, Kümmerli R. Combining antibiotics with antivirulence compounds can have synergistic effects and reverse selection for antibiotic resistance in Pseudomonas aeruginosa. PLoS Biol. 2020;18:e3000805.

2. Podoll JD, Liu Y, Chang L, Walls S, Wang W, Wang X. Bio-inspired synthesis yields a tricyclic indoline that selectively resensitizes methicillin-resistant Staphylococcus aureus (MRSA) to $\beta$-lactam antibiotics. Proc Natl Acad Sci U S A. 2013;110:15573-8.

3. Dettweiler M, Melander RJ, Porras G, Risener C, Marquez L, Samarakoon T, Melander C, Quave CL. A Clerodane Diterpene from Callicarpa americana Resensitizes Methicillin-Resistant Staphylococcus aureus to $\beta$-Lactam Antibiotics. ACS Infect Dis. 2020;6:1667-73.

4. Ng SY, Ong KX, Surendran ST, Sinha A, Lai JJH, Chen J, Liang J, Tay LKS, Cui L, Loo HL, Ho P, Han J, Moreira W. Hydrogen Sulfide Sensitizes Acinetobacter baumannii to Killing by Antibiotics. Front Microbiol. 2020;11:1875.

5. Li Z, Tan J, Shao L, Dong X, Ye RD, Chen D. Selenium-mediated protection in reversing the sensitivity of bacterium to the bactericidal antibiotics. J Trace Elem Med Biol. 2017;41:23-31. 
6. Ersoy SC, Abdelhady W, Li L, Chambers HF, Xiong YQ, Bayer AS. Bicarbonate Resensitization of Methicillin-Resistant Staphylococcus aureus to $\beta$-Lactam Antibiotics. Antimicrob Agents Chemother. 2019;63:e00496-19.

7. Resensitization of sulfonamide fast bacteria. JAMA. 1943;121:680.

8. Borselli D, Lieutaud A, Thefenne $H$, Garnotel E, Pagès JM, Brunel JM, Bolla JM. Polyamino-Isoprenic Derivatives Block Intrinsic Resistance of P. aeruginosa to Doxycycline and Chloramphenicol In Vitro. PLoS One. 2016;11:e0154490.

9. Blanchet M, Borselli D, Rodallec A, Peiretti F, Vidal N, Bolla JM, Digiorgio C, Morrison KR, Wuest WM, Brunel JM. Claramines: A New Class Of BroadSpectrum Antimicrobial Agents With Bimodal Activity. ChemMedChem. 2018;13:1018-27.

10. Sun $H$, Zhang $\mathrm{Q}$, Wang $\mathrm{R}$, Wang $\mathrm{H}$, Wong $\mathrm{Y}$, Wang $\mathrm{M}$, Hao $\mathrm{Q}$, Yan $\mathrm{A}$, Kao RY, Ho PL, Li H. Resensitizing carbapenem- and colistin-resistant bacteria to antibiotics using auranofin. Nat Commun. 2020;11:5263.

11. Ng SY, Ong KX, Surendran ST, Sinha A, Lai JJH, Chen J, Liang J, Tay LKS, Cui L, Loo HL, Ho P, Han J, Moreira W. Hydrogen Sulfide Sensitizes Acinetobacter baumannii to Killing by Antibiotics. Front Microbiol. 2020;11:1875.

12. Shatalin K, Shatalina $E_{1}$ Mironov A, Nudler E. $\mathrm{H}_{2} \mathrm{~S}$ : a universal defense against antibiotics in bacteria. Science. 2011;334:986-90.

13. Shukla $P$, Khodade VS, SharathChandra $M$, Chauhan $P$, Mishra $S$, Siddaramappa S, Pradeep BE, Singh A, Chakrapani H. "On demand" redox buffering by $\mathrm{H}_{2} \mathrm{~S}$ contributes to antibiotic resistance revealed by a bacteria-specific $\mathrm{H}_{2} \mathrm{~S}$ donor. Chem Sci. 2017;8:4967-72.

14. Kortright KE, Chan BK, Koff JL, Turner PE. Phage Therapy: A Renewed Approach to Combat Antibiotic-Resistant Bacteria. Cell Host Microbe. 2019;25:219-32.

15. Gordillo Altamirano F, Forsyth JH, Patwa R, Kostoulias X, Trim M, Subedi D, Archer SK, Morris FC, Oliveira C, Kielty L, Korneev D, O'Bryan MK, Lithgow TJ, Peleg AY, Barr JJ. Bacteriophage-resistant Acinetobacter baumannii are resensitized to antimicrobials. Nat Microbiol. 2021;6:157-61.

16. Kasman LM, Porter LD. Bacteriophages. 2020 0ct 1. In: StatPearls [Internet]. Treasure Island (FL): StatPearls Publishing;2021.

17. Coates $A R, H u$ Y. Novel approaches to developing new antibiotics for bacterial infections. Br J Pharmacol. 2007;152:1147-54.

18. Yosef I, Manor M, Kiro R, Qimron U. Temperate and lytic bacteriophages programmed to sensitize and kill antibiotic-resistant bacteria. Proc Natl Acad Sci U S A. 2015;112:7267-72.
19. Torres-Barceló $\mathrm{C}$. The disparate effects of bacteriophages on antibioticresistant bacteria. Emerg Microbes Infect. 2018;7:168.

20. Bragg $R$, van der Westhuizen W, Lee JY, Coetsee E, Boucher C. Bacteriophages as potential treatment option for antibiotic resistant bacteria. Adv Exp Med Biol. 2014;807:97-110.

21. Kortright KE, Chan BK, Koff JL, Turner PE. Phage Therapy: A Renewed Approach to Combat Antibiotic-Resistant Bacteria. Cell Host Microbe. 2019;25:219-32.

22. Melander RJ, Melander C. The Challenge of Overcoming Antibiotic Resistance: An Adjuvant Approach? ACS Infect Dis. 2017;8:559-63.

23. Douafer H, Andrieu V, Phanstiel O, Brunel JM. Antibiotic Adjuvants: Make Antibiotics Great Again! J Med Chem. 2019;62:8665-81.

24. Wright GD. Antibiotic Adjuvants: Rescuing Antibiotics from Resistance. Trends Microbiol. 2016;24:862-71.

25. Upadhyay A, Upadhyaya I, Kollanoor-Johny A, Venkitanarayanan K. Combating pathogenic microorganisms using plant-derived antimicrobials: a minireview of the mechanistic basis. Biomed Res Int. 2014;2014:761741.

26. Cowan MM. Plant products as antimicrobial agents. Clin Microbiol Rev. 1999;12:564-82.

27. Gill AO, Holley RA. Mechanisms of bactericidal action of cinnamaldehyde against Listeria monocytogenes and of eugenol against L. monocytogenes and Lactobacillus sakei. Appl Environ Microbiol. 2004;70:5750-5.

28. Kuroda M, Nagasaki S, Ohta T. Sesquiterpene farnesol inhibits recycling of the C55 lipid carrier of the murein monomer precursor contributing to increased susceptibility to beta-lactams in methicillin-resistant Staphylococcus aureus. J Antimicrob Chemother. 2007;59:425-32.

29. Podoll JD, Liu Y, Chang L, Walls S, Wang W, Wang X. Bio-inspired synthesis yields a tricyclic indoline that selectively resensitizes methicillin-resistant Staphylococcus aureus (MRSA) to $\beta$-lactam antibiotics. Proc Natl Acad Sci U S A. 2013;110:15573-8.

30. Aqil F, Khan MS, Owais M, Ahmad I. Effect of certain bioactive plant extracts on clinical isolates of beta-lactamase producing methicillin resistant Staphylococcus aureus. J Basic Microbiol. 2005;45:106-14.

31. Silva ON, Torres MDT, Cao J, Alves ESF, Rodrigues LV, Resende JM, Lião LM, Porto WF, Fensterseifer ICM, Lu TK, Franco OL, de la Fuente-Nunez C. Repurposing a peptide toxin from wasp venom into antiinfectives with dual antimicrobial and immunomodulatory properties. Proc Natl Acad Sci U S A. 2020;117:26936-45. 